\title{
CAMBRIDGE UNIVERSITY NATURAL RADIOCARBON MEASUREMENTS VII
}

\author{
H. GODWIN, E. H. WILLIS and V. R. SWITSUR \\ Cambridge University* \\ INTRODUCTION
}

The dates and activity measurements given below have been obtained during 1963 and 1964, and have been made with $\mathrm{CO}_{2}$ at $3 \mathrm{~atm}$ pressure in a proportional gas-counter as described in previous contributions from this laboratory. We have again concentrated chiefly upon research projects pursued in the University Sub-department of Quaternary Research, but have continued final determinations also in the series of samples of $\mathrm{CO}_{2}$ collected in the lower stratosphere and described in our date list VI.

We particularly wish to acknowledge the help of G. A. Sutton, Technical Assistant in the Radiocarbon Dating Laboratory and of the Scientific Assistants C. A. Raven and M. A. Hall. Dr. Willis has resigned his University Post to move to Isotopes Inc., Westwood, New Jersey and he has been succeeded by Dr. V. R. Switsur. Correction for fractionation error has been made in the case of a few samples specially indicated in the text.

\section{SAMPLE DESCRIPTIONS}

BRITISH ISLES

\section{A. Post-glacial vegetational history}

\section{Bloak Moss series, Ayrshire, Scotland}

Dr. Judith Turner, of the Cambridge Sub-dept. of Quaternary Research has been engaged in reconstructing, by means of very detailed pollen analyses at close vertical intervals, the effects of prehistoric forest clearance and early

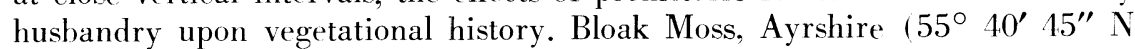
Lat, $4^{\circ} 36^{\prime} \mathrm{W}$ Long: Grid ref. NS/363463) was selected as specially suited. A peat monolith was extracted and removed to the Cambridge lab., and after detailed pollen analyses had been completed, slices of peat $2 \mathrm{~cm}$ thick were cut at the crucial levels for $\mathrm{C}^{14}$ dating. Coll. Aug. 1962 by Judith Turner, St. Aidan's College, Univ. of Durham, England.

\section{Q-727. Bloak Moss, Ayrshire, $183 / 5 \mathrm{~cm} \quad 3825 \pm 110$

Q-727. Bloak Moss, Ayrshire, 1835 B.c.

Highly humified peat: beginning of continuous grass and Plantago pollen curves.

\section{Q-726. Bloak Moss, Ayrshire, $165 / 7 \mathrm{~cm} \quad 3320 \pm 105$}

Highly humified Sphagnum-Calluna peat: first temporary forest clearance.

* Radiocarbon Dating Laboratory, 5 Salisbury Villas, Station Road, Cambridge, and University Sub-department of Quaternary Research, Botany School, Cambridge, England. 


\title{
$\begin{array}{ll}\text { Q-725. Bloak Moss, Ayrshire, } 133 / 5 \mathrm{~cm} & 3050 \pm 105 \\ 1100 \text { в.c. }\end{array}$ \\ 1100 в.C.
} ance.

Highly humified Sphagnum-Calluna peat: second temporary forest clear-

\section{Q-724. Bloak Moss, Ayrshire, 109/11 cm}

$3170 \pm 105$

1220 в.c.

Weakly humified Sphagnum imbricatum peat: third temporary forest clearance.

\section{Q-723. Bloak Moss, Ayrshire, 89/91 cm}

$2375 \pm 90$

425 в.c.

Weakly humified Spragnum imbricatum peat: fourth temporary forest clearance.

\section{Q-722. Bloak Moss, Ayrshire, 79/81 cm}

$1535 \pm 90$

Weakly humified Sphagnum imbricatum pet: beginnig 415 B.c. clearance with high grass pollen frequencies.

\section{Q-721x. Bloak Moss, Ayrshire, $58 / 9 \mathrm{~cm}$}

$1495 \pm 90$

Highly humified bog peat: adjacent to Q-721 and check upon it.

\section{Q-721. Bloak Moss, Ayrshire, 55/7 cm}

\author{
$1370 \pm 90$ \\ $1455 \pm 90$ \\ A.D. 580 \\ A.D. 495
}

Junction of weakly humified and highly humified peat: end of prolonged clearance began with Q-722 at 79/81 cm.

General Comment on Bloak Moss series: the $\mathrm{C}^{14}$ dates establish the time of minor forest clearances in late Neolithic, middle Bronze Age and early Iron Age times, and a more general clearance in early post-Roman time. The dates also make it apparent that in this bog there were phases of very slow peat accumulation (184 to $166 \mathrm{~cm}$ in ca. $600 \mathrm{yr}$ and 110 to $90 \mathrm{~cm}$ in ca. $800 \mathrm{yr}$ ) as against phases of very rapid growth $(160$ to $110 \mathrm{~cm}$ and 80 to $56 \mathrm{~cm}$ in periods of the order of 1 or 2 centuries), but these show no clear relation to the (local) humification sequence, and there is a long time lapse represented by very fresh peat.

\section{Duartbeg series, Sutherlandshire, Scotland}

Sediments were taken from the $\mathrm{N}$ end of a small loch $1 / 4 \mathrm{mi}$ S of Loch Duartbeg ( $58^{\circ} 08^{\prime} \mathrm{N}$ Lat, $5^{\circ} 02^{\prime} 20^{\prime \prime} \mathrm{W}$ Long: Grid ref. 166384), alt ca. $50 \mathrm{ft}$ O.D. Coll. June 1963 by N. T. Moar and R. G. West (Cambridge Sub-dept. of Quaternary Research) and R. Cullingford; sampling by wide Hiller-type corer for one-shot $\mathrm{C}^{14}$ samples. Stratigraphic sequence is as follows: 560 to $575 \mathrm{~cm}$ base of organic deposits on stoney blue clay; 400 to $560 \mathrm{~cm}$ fine detritus mud; 315 to $400 \mathrm{~cm}$ coarse detritus mud; 0 to $315 \mathrm{~cm}$ coarse fibrous peat sharply cut off from underlying muds at $315 \mathrm{~cm}$. Pollen analyses were made throughout by N. T. Moar and samples for carbon dating came from critical pollen frequency changes. 
Q-753. Duartbeg, Sutherlandshire, 544/6 cm

Fine detritus organic mud: Pollen Zone VIla with preponderant Betula, frequent Ulmus, Quercus, Alnus, Salix, Juniperus and Corylus. beginning of rise in Pinus.

\section{Q-748. Duartbeg, Sutherlandshire, $454 / 6 \mathrm{~cm} \quad \mathbf{5 2 2 0} \pm 115$}

Fine detritus organic mud: Pollen Zone VIIa, as for Q-753, but with $35 \%$ Pinus max, end of Juniperus curve and beginning of rise in Alnus frequencies.

\section{Q-741. Duartbeg, Sutherlandshire, $418 / 20 \mathrm{~cm} \quad 3900 \pm 105$}

Fine detritus organic mud: top of Pollen Zone VIIa marked by steep decline of Pinus from maximum, and of Ulmus, and sharp rise of Quercus.

Q-757. Duartbeg, Sutherlandshire, $305 / 10 \mathrm{~cm} \quad 3690 \pm 110$

Coarse fibrous peat containing abundant Sphagnum, some Betula, Myrica and Carices: level of rapid decline in the AP/NAP ratio, primarily related to abrupt overgrowth of open water by peat-bog, but also showing initial maximum and continuing curve for Plantago lanceolata, indicative of clearance. General Comment on Duartbeg series: it seems possible that the dates for Q-753 and Q-748 give a further date for the "Upper Forestian" of Scottish peat-bogs. The big time gap between Q-741 and Q-748 (1300 yr) suggests a gap in the depositional sequence, possibly due to low water-levels. On chronology from England the clearance at 1740 в.c. (Q-757) would be early Bronze Age.

\section{Bigholm Burn series, Dumf riesshire, Scotland}

Three further samples are here reported from the series fully described in Cambridge date-list VI. From section on E hank of Bigholm Burn, Dumfriesshire ( $55^{\circ} 07^{\prime} 15^{\prime \prime} \mathrm{N}$ Lat, $3^{\circ} 04^{\prime} 30^{\prime \prime} \mathrm{W}$ Long), Natl. Grid ref. 316812, alt ca. $480 \mathrm{ft}$ O.D. Coll. 1962 by N. T. Moar of Cambridge Sub-dept. of Quaternary Research, who also made pollen analyses.

\section{Q.699. Bigholm Burn, Dumf riesshire, No. $6 \quad 8650 \pm 165^{*}$}

Dark brown Phragmites peat, covering transition from brown organic muds, at very sharp decline in pollen of aquatic plants, and beginning of first rise of the AP/NAP ratio. Taken as opening of Zone IV, after transition Zone III/IV at opening of the Flandrian (Post-glacial). Betula becoming dominant in tree pollen with some Juniperus and low frequency of Pinus and Salix.

* (including correction for fractionation)

\section{Q-700. Bigholm Burn, Dumf riesshire}

$7735 \pm 155$

5785 в.c.

Phragmites peat, uppermost $10 \mathrm{~cm}$ of layer $40 \mathrm{~cm}$ thick of which Q-699 represents the base. Top of Pollen Zone IV with Betula dominant, infrequent Pinus, Juniperus and Salix and first low frequencies of Corylus.

\section{Q-702. Bigholm Burn, Dumf riesshire}

$5475 \pm 120$

3525 в.c.

Compressed wood peat (Betula), near base of a $70 \mathrm{~cm}$ thick layer and 
immediately superjacent to Q-701 (Cambridge VI). Pollen-zone late VI. Ulmus and Alnus curves beginning, Quercus beginning to rise and Corylus at maximum.

General Comment on Bigholm Burn series: although the dates already published (Cambridge VI) for Late-Weichselian samples at this site (Q-694, 695) correspond with expectation based upon stratigraphy and pollen evidence, those from the organic layers above the Zone III solifluxion gravels (i.e. post-glacial) are all younger than expected. In comparison with the equivalent dated pollen zones at Scaleby Moss (Cambridge I, II) the Bigholm samples are too young: Q-697 by ca. 400 yr, Q-699 by ca. 1300 yr, Q-700 by ca. 1200 yr, Q-701 by ca. $1500 \mathrm{yr}$ and Q.702 by over 3000 . The Scaleby Moss dates are well supported internally and by other British and European dates, and as Bigholm and Scaleby are a very short distance apart it is highly unlikely that there has been so great a lag in the migration of successive woodland associations between them. It is more probable that there has been a massive contamination by younger carbon from above, a suggestion borne out by the great discrepancy of the uppermost sample (Q-702); the growth of many generations of trees in situ may well always be accompanied by downward growth of young roots causing effects of this kind.

\section{Whixall Moss series, site 3, Shropshire}

This raised bog has been the site of preliminary pollen analytic studies (Hardy, 1939) and recently by J. Turner (1964) who made large counts at vertical intervals of only $1 \mathrm{~cm}$ as a means of characterizing the effects of primitive clearance and hushandry upon the general vegetational cover. The site ( $52^{\circ} 55^{\prime} \mathrm{N}$ Lat, $2^{\circ} 46^{\prime} \mathrm{W}$ Long), shows a pine stump layer already dated $(Q-383,2307 \pm 110)$, and a further sample $30 \mathrm{~cm}$ below it already published (Q-467, $3238 \pm 115$ ). Coll. 1960 by J. Turner, Univ. Sub-dept. of Quaternary Research, Cambridge.

\section{Q-466. Whixall Moss, Site 3, Shropshire, $\quad 2710 \pm 90$ $65-66 \mathrm{~cm}$ 760 B.C.}

Highly humified Sphagnum peat, taken from a level indicating the end of a long period of maximum agricultural activity (Stages C, D and E of Turner). with high frequencies of grasses. Plantago and Pteridium, following big decreases in forest tree pollen, notably Quercus, Ulmus and Tilia.

\section{Q-468. Whixall Moss, Site 3, Shropshire, $\quad 2000 \pm 90$ $42-43 \mathrm{~cm}$ \\ 50 в.C.}

Highly humified Sphagnum peat, from end of a short period of agricultural activity (Stage H of Turner) marked by big decrease in pollen of Quercus and Corylus and much increased values of Plantago, Pteridium and grasses. General Comment on Whixall Moss series: the four dates now available occur in the expected sequence and provide a time-scale for the vegetation changes identified by pollen analyses; the two dates here given confirm the earlier view of Turner that $1 \mathrm{~cm}$ of peat took 20 to $30 \mathrm{yr}$ to form. The mean rate now seems about $27.5 \mathrm{gr} / \mathrm{cm}$. the span of each separate pollen analysis. The stage of sustained agricultural activity identified by Turner (C. D, E) is shown to 
extend from ca. 1280 to ca. 760 B.c., i.e., it falls in middle to late Bronze Age, whilst the minor clearance (possibly $250 \mathrm{yr}$ long) is shown to end ca. 50 B.C., i.e., in the pre-Roman Iron Age. The pine stub layer presumably indicates a stage of dryness ca. 360 B.C.

\section{B. Land-and Sealevel Changes}

Continuing the research of the Univ. Sub-dept. of Quaternary Research, Cambridge there are two series of samples from SE England submitted by D. M. Churchill, two samples related to the ' $25 \mathrm{ft}$ raised beach' of SW Scotland. and one from the Humber; they all extend the coastal datings given in Cambridge I, III, V, VI.

\section{Tilbury Docks series}

(On the $\mathrm{N}$ shore of the Thames estuary at Tilbury Dock $\left(51^{\circ} 27^{\prime} 26^{\prime \prime} \mathrm{N}\right.$ lat, $0^{\circ} 21^{\prime} 54^{\prime \prime} \mathrm{E}$ Long), excavations have afforded D. M. Churchill the means to study the sediments: peat beds alternating with estuarine and freshwater clays. Coll. Nov. 1963 by D. M. Churchill.

\section{Q-790. Tilbury Docks, No. 1}

$$
\begin{aligned}
& 6940 \pm 120 \\
& 7120 \pm 120 \\
& 4990 \text { в.C. } \\
& 5170 \text { в.C. }
\end{aligned}
$$

Phragmites peat from a peat bed $6 \mathrm{ft}$ thick overlying blue-grey silty clay with freshwater molluses, and overlaid by soft grey peaty clay. From bore 8185. $50 \mathrm{ft}$ from surface at $-35 \mathrm{ft}$ O.D. Pollen Zone VIIa.

\section{Q-791. Tilbury Docks, No. 2}

Phragmites peat with twigs, in a lens in peaty blue-grey clay of estuarine or marine origin. From bore 8185, $42 \mathrm{ft}$ from surface and $-27 \mathrm{ft}$ O.D. Pollen Zone VIla.

\section{Q-811. Tilbury Docks, No. 3}

Sandy wood and sedge peat from a peat bed $1 \mathrm{ft} 3 \mathrm{in}$. thick with fine charcoal, overlying grey clayey sands flanking channel and overlain by peaty clay. From hore 8180, $29 \mathrm{ft}$ from surface and -26 ft O.D. Pollen Zone VIIa.

\section{Q-810. Tilbury Docks, No. 4}

Sedge peat from a 2 -ft peat bed with fine charcoal separated from Q-811 underneath by peaty clay and overlain by grey estuarine clay containing Scrobicularia. From hore 8180, $21 \mathrm{ft}$ from surface and $-18 \mathrm{ft}$ ().D. Pollen Zone VIIa.

\section{Q-792. Tilbury Docks, No. 5

Phragmites peat from a peat bed, $2 \mathrm{ft}$ thick, underlain by a hlue-grey Phragmites peaty clay of estuarine origin, and overlain hy grey estuarine 
Scrobicularia clay. From bore 8182, $28.5 \mathrm{ft}$ from surface and $-16 \mathrm{ft}$ O.D. Pollen Zone VIIb.

\section{Q-793. Tilbury Docks, No. 6}
$2467 \pm 110$

Phragmites peat from uppermost peat bed $1 \mathrm{ft} 6$ in. thick overlying estuarine Scrobicularia clay, and overlain by grey clay, possibly estuarine. From bore $8182,21 \mathrm{ft}$ from surface and $-8.5 \mathrm{ft}$ O.D. Pollen Zone VIII.

Comments on Tilbury Docks series: the six samples come from three different bores and it is not easy on the basis of pollen analysis and lithology to correlate the peat beds. The $\mathrm{C}^{14}$ dates however are in the sequence of depth below mean sealevel, recording stages of a $35-\mathrm{ft}$ marine transgression between ca. 5000 в.c. and the present day, including at least $18 \mathrm{ft}$ since 3000 в.c. The dates accord with the previous dates of the three pollen zones involved.

\section{Saddlebow series, King's Lynn, Norfolk}

As part of continuing study of the stratigraphy and geological history of the Fenland basin of East Anglia (Godwin, 1960; Willis, 1961) four $\mathrm{C}^{14}$ dates have already been published (Cambridge III) for the upper and lower surfaces respectively of the so-called "Upper peat bed" that consistently overlies the "Fen Clay," and that is itself overlain by clays and silts of which the latter are known to be of Romano-British age. One of the important sites was an exposure in the bank of the new flood-relief channel of the River Great Ouse ca. $0.5 \mathrm{mi} \mathrm{N}$ of Saddlebow village $\left(52^{\circ} 42^{\prime} 40^{\prime \prime} \mathrm{N}\right.$ Lat, $0^{\circ} 23^{\prime} 10^{\prime \prime} \mathrm{E}$ Long). The date for the contact of the peat and overlying clay appeared to be ca. 0 A.D. (Q-549, $1875 \pm 110$; Q-550, 2070 \pm 110 ), but at a similar site on the same channel and not far away (Magdalene Bend) a much greater age was obtained for apparently the same lithological contact $(Q-547,3305 \pm 120)$. Fortunately the original monolith from Saddlebow had been retained, and now three further samples have been dated from the upper half of the peat bed. The whole monolith is unfortunately penetrated by vertical uncompressed rhizomes and rootlets of Phragmites.

\section{Q-805. Saddlebow, King's Lynn, Norfolk, No. $3 \quad 2495 \pm 110$}

Fen peat from the top ( 0 to $1 \mathrm{in}$.) of the upper peat bed in contact with the overlying blue clay, and adjacent to Q-549.

\section{Q-806. Saddlebow, King's Lynn, Norfolk, No. $4 \quad 2275 \pm 100$}

Fen peat from 5 to $6 \mathrm{in}$. below contact with overlying blue clay.

\section{Q-807. Saddlebow, King's Lynn, Norfolk, No. $52377 \pm 100$}

Fen peat from 9 to $10 \mathrm{in}$. below contact with overlying blue clay.

Comment on the Saddlebow series: the three dates now reported are older than the two reported earlier. They are still much younger than the top of the same peat bed at Magdalene Bend, where possibly therefore erosion took place be- 
fore or during deposition of the overlying clay. The absence of an age gradient in the $10 \mathrm{in.}$ from Q-805 to Q-807 is unsatisfactory. It seems unsafe to deduce the onset of this marine transgression from these dates although they appear to indicate that it was in the pre-Roman Iron Age.

Q-818. Gatehouse of Fleet, Kirkcudbrightshire, No. $1 \begin{aligned} & 6244 \pm 140 \\ & 4294 \text { в.c. }\end{aligned}$

Wood (Quercus) (54 $52^{\prime} \mathrm{N}$ Lat, $4^{\circ} 12^{\prime} \mathrm{W}$ Long), from the top of a lens of peat $2 \mathrm{ft}$ thick and $80 \mathrm{ft}$ diam overlain by $5 \mathrm{ft}$ of dark grey silts which form an extensive flat at about $+30 \mathrm{ft}$ O.D., underlain by a variable thickness of 1.5 to $5.0 \mathrm{ft}$ of loose gravel and below this $30 \mathrm{ft}$ of grey clay. The clays are ascribed to the ' $25 \mathrm{ft}$ raised beach', and this sample must represent a late stage in its formation. Coll. 1962 by W. W. Bishop, Uganda Mus., Kampala. Comment: this date agrees well with those from Lochar Moss (Q-638, 6645 \pm 120$)$ and Newton Stewart $(Q-639,6159 \pm 120)$, which are also for samples near the top or above the 25-ft raised beach deposits (Cambridge V; Godwin, 1960).

\section{Q-815. Redkirk Point, Dumf riesshire}

$10,300 \pm 185$

Wood (Populus) (Grid ref. 35/056680; 54 59' N Lat, $3^{\circ} 28^{\prime}$ W Long). from laminated peat bed covered by ca. $9 \mathrm{ft}$ of sandy grey clay, succeeded by a higher peat bed, 9 in. thick, dated $8135 \pm 150$ (Q-637), which is overlain by ca. $12 \mathrm{ft}$ of Carse clays. The sampled peat has abundant beetle remains, in- 
Q-802.

$$
\delta \mathbf{C}^{14}+\mathbf{2 0} \%
$$

Wheat (Triticum) grains harvested in A.D. 1887, and kept sealed since, from laboratory of Messrs. Spiller \& Co., Cambridge. Value expressed in relation to 1859 wood standard ( $\mathrm{cf}$. Willis, Tauber \& Münnich, 1960).

Correction to Cambridge VI, Radiocarbon, vol. 6, p. 126.

Q-760. Weston Wood, Albany, Surrey, W.W.63. 'Albany' should read 'Albury'.

Date lists:

British Museum II

REFERLNCES

Cambridge I

Cambridge II

Cambridge III

Cambridge V

$\begin{array}{ll}\text { Cambridge VI } & \text { Godwin and Willis, } 1963 \\ \text { National Physical Laboratory I } & \text { Callow, Baker and Pritchard, } 1963\end{array}$

Barker and Mackey, 1960

Godwin and Willis, 1959

Godwin and Willis, 1960

Godwin and Willis, 1961

Godwin and Willis, 1962

Godwin, H., 1960, Radiocarbon dating and Quaternary history in Britain: Royal Soc. (London) Proc., B, v. 153, p. 287.

Hardy, E. M., 1939, Studies in the Post-glacial history of British Vegetation V. The Shropshire and Flint-Maelor mosses: New Phvtologist. v. 38 n 364 